\title{
Prevalence and Genotypes of Hepatitis G Virus among Hemodialysis Patients in Eastern Anatolia, Turkey
}

\author{
Aykut Ozdarendeli ${ }^{a}$ Zulal A. Toroman ${ }^{a}$ Ahmet Kalkan ${ }^{b}$ Süleyman S. Kilic ${ }^{b}$ \\ Mehmet Ozden ${ }^{c}$ Mehmet Z. Doymaz ${ }^{\mathrm{a}}$ \\ Departments of a Microbiology and Clinical Microbiology, ${ }^{b}$ Infectious Diseases and ${ }^{\mathrm{c}}$ Immunology, \\ Firat University Medical School, Elazig, Turkey
}

\section{Key Words}

Hepatitis G virus - Hemodialysis patients - Genotypes •

East Anatolia, Turkey

\begin{abstract}
Objectives: To study the prevalence and genotype distribution of hepatitis G virus (HGV) in hemodialysis patients in East Anatolia, Turkey. Subjects and Materials: Eighty-nine hemodialysis patients and 30 healthy individuals were analyzed by using reverse-transcriptase nested polymerase chain reaction with primers specific for $5^{\prime}$ untranslated region. HGV genotyping was performed by PCR and three randomly selected HGV-positive samples were sequenced. Results: Of the 89 hemodialysis patients, HGV RNA was detected in 9 (10.2\%). All of our isolates were assigned to genotype 2. Conclusion: Our results showed that hemodialysis patients carry the risk for HGV infection in East Anatolia, Turkey.
\end{abstract}

Copyright (C) 2005 S. Karger AG, Base

\section{Introduction}

Hepatitis $\mathrm{G}$ virus (HGV) is a recently described member of flaviviruses. The genome of the virus consists of single-stranded RNA and has a positive polarity. Similar to other members of the flaviviridae, it contains a single open reading frame that encodes the viral polyprotein [1, 2]. The natural history of $\mathrm{HGV}$ infection is at present not fully understood. The potential of HGV to cause hepatitis in humans is questionable. Controversial data exist concerning whether or not HGV replicates in the liver [3-6].

$\mathrm{HGV}$ is highly prevalent among population groups at risk of parenterally transmitted viral agents, but it has also a worldwide distribution in other non-risk population groups. Hemodialysis (HD) patients have a high risk of blood-borne viral infections [7]. Some of the most common viral infections are caused by hepatotropic or other hepatitis-associated viruses such as hepatitis B virus (HBV) [8], hepatitis C virus (HCV) [9], HGV [10] and transfusion-transmitted virus [11]. In recent years, a high prevalence of $\mathrm{HGV}$ infection among end-stage renal disease and chronic HD patients has been well documented, varying between 6 and 44\%, in different countries [1215]. Analysis of the $5^{\prime}$ untranslated region (UTR) has led to the suggestion that variants of $\mathrm{HGV}$ can be divided into five genotypes [16]. Genotype 1 is prevalent in West and Central Africa; genotype 2 in Europe, North America and East Africa, Pakistan and Japan; genotype 3 in parts of Asia; genotype 4 in South-East Asia, and genotype 5 in South Africa $[16,17]$. Investigation of genetic diversity among sequences of different isolates of a virus

\section{KARGER \\ Fax +41613061234 E-Mail karger@karger.ch} www.karger.com
C 2005 S. Karger AG, Basel 1011-7571/05/0142-0102\$22.00/0

Accessible online at:

www.karger.com/mpp
Aykut Ozdarendeli, PhD

Department of Microbiology and Clinical Microbiology

Firat University Medical School, TR-23119 Elazig (Turkey)

Tel. +90 4242370000 , ext. 6686, Fax +90 4242379138

E-Mail aozdarendeli@hotmail.com 
Table 1. Oligonucleotides used for amplification and genotyping of $\mathrm{HGV}$ in this study

\begin{tabular}{|c|c|c|}
\hline Primer & Sequence specificity $^{1}$ & Sequence polarity \\
\hline HG1 & 5'-GGTCGTAATCCCGGTCACC-3' & universal/sense \\
\hline HG1R & 5'-CCCACTGGTCCTTGTCAACT-3' & universal/antisense \\
\hline HG2R & 5'-ATTGAAGGGCGACGTGGACC-3' & universal/antisense \\
\hline \multicolumn{3}{|c|}{ (6) } \\
\hline G38 & 5'-TGTAATAAGGACCCGGCGMT-3' & type 1 -specific/sense \\
\hline G41 & 5'-TGGTCAAGGTCCCTCTG-3' & type 3-specific/sense \\
\hline \multicolumn{3}{|l|}{ Mix B } \\
\hline G35 & 5'-GGGTCTTAAGAGAAGGTTAAGA-3' & type 2-specific/sense \\
\hline G40 & 5'-GGGTYAAGGCACCTCTTA-3' & type 4-specific/sense \\
\hline
\end{tabular}

has become important because variants show different patterns of virulence, reactivity, and response to antiviral therapy $[10,17]$. The present study was undertaken to determine the prevalence and genotype distribution of HGV in HD patients in Elazig, East Anatolia, Turkey.

\section{Subjects and Methods}

\section{Subjects}

We studied 89 patients ( 46 men and 43 women; mean age 49.4 \pm 17.6 years) with renal failure who were undergoing HD at the government hospital hemodialysis units. The patients had been on maintenance HD for a mean period of $89.7 \pm 15.3$ weeks (range, 2-728 weeks). Thirty healthy individuals ( 18 men and 12 women; $42.4 \pm 19.6$ years) who did not belong to any risk group for viral hepatitis served as negative controls. Sera from the HD patients and the control group were tested for markers of $\mathrm{HBV}$ and $\mathrm{HCV}$ infections, and serum levels of alanine aminotransferase (ALT) were measured. Blood samples were collected and centrifuged immediately and stored at $-80^{\circ} \mathrm{C}$ until used. The study was approved by the Ethics Committee of the institution, and all patients gave informed consent.

Serological Markers of Hepatitis B and C Infections, and

Serum ALT Values

HBV surface antigen (HBsAg) was detected with commercially available enzyme-linked immunosorbent assays (ELISA, Abbott Diagnostics, Dartford, UK). Detection of anti-HCV antibody was measured using commercially available second-generation ELISA (Abbott Diagnostics). The serum ALT values were measured by using Olympus AU 600 autoanalyzer (Olympus Corp., Japan). The level of ALT has an upper reference range of $40 \mathrm{U} / 1$.

\section{Determination of HGV by Reverse Transcription Nested}

Polymerase Chain Reaction (RT-n-PCR)

RNA was obtained from serum by EZ-RNA Total RNA Isolation Kit (Biological Industries Co. Beit Haemek). RT was performed by incubating the template (approximately $100 \mu \mathrm{l}$ of serum) in the presence of $50 \mathrm{p} M$ outer antisense primer (HG1R; nt 381 to
$400)$ and $100 \mathrm{U}$ of Moloney murine leukemia reverse transcriptase (Promega, Madison, Wisc., USA) for $1 \mathrm{~h}$ at $37^{\circ} \mathrm{C}$. PCR amplification of cDNA was carried out in a $50-\mu l$ volume by using HG1R and outer sense primer (HG1; nt 139 to 158). After a denaturation step $\left(5 \mathrm{~min}\right.$ at $\left.94^{\circ} \mathrm{C}\right), 33$ cycles of PCR followed with one cycle consisting of denaturation $\left(30 \mathrm{~s} 94^{\circ} \mathrm{C}\right)$, annealing $\left(1 \mathrm{~min} 55^{\circ} \mathrm{C}\right)$ and primer extension $\left(1 \mathrm{~min} 72^{\circ} \mathrm{C}\right)$. Nested PCR was performed in a $50-\mu \mathrm{l}$ volume after transfer of $2 \mu \mathrm{l}$ from the first round of PCR to a mix containing $50 \mathrm{p} M$ inner sense primer (HG2; nt 163 to 182) and an inner antisense primer (HG2R; nt 331 to 350). The nested PCR was performed after a denaturation step as given above except that 40 cycles instead of 33 cycles were run. Amplicons of $188 \mathrm{bp}$ were expected. The PCR products were electrophoresed on a $3 \%$ agarose gel, stained with ethidium bromide and visualized under UV light.

\section{HGV Genotyping by PCR}

$\mathrm{HGV}$ genotyping by PCR was performed as described previously [18]. Briefly, the RNA was extracted from 100- $\mu 1$ serum samples. The 5' UTR region of the HGV genome was amplified with universal primers (HG1 and HG1R). Then, two second-round PCRs were carried out for each sample, with the common universal antisense primer (HG2R) and two different mixtures (mix A and B) including type-specific sense primer pairs shown in table 1. A $2-\mu l$ aliquot of the first PCR product was subjected to two tubes containing the second sets of each of the inner primer pairs, deoxynucleotides, Taq DNA polymerase and PCR buffer, and the same PCR parameters as in the first reaction. To distinguish genotype 2 from genotype 4 by agarose gel electrophoresis, we amplified an amplicon in 161 bp length, which is the same size as genotype 4, as a marker, using pSV2-Cat cloning vector (accession number M777788) as a template with primer $15^{\prime}$-AATGTTGAGAGTCAGCAGTAGCC-3' and primer 2 5'-GAATCAGTA GTTTAACACAT $-3^{\prime}$ that bind to pSV2-Cat cloning vector at positions 4450 and 4611, respectively. Amplified products were visualized after electrophoresis through a $3 \%$ agarose gel stained with ethidium bromide.

Nucleotide Sequence of HGV Isolates

To confirm the validity of the HGV genotyping system by PCR, three amplified DNA fragments were subcloned into pGEM-T vector (Promega, Madison, Wisc., USA) before being subjected to se- 


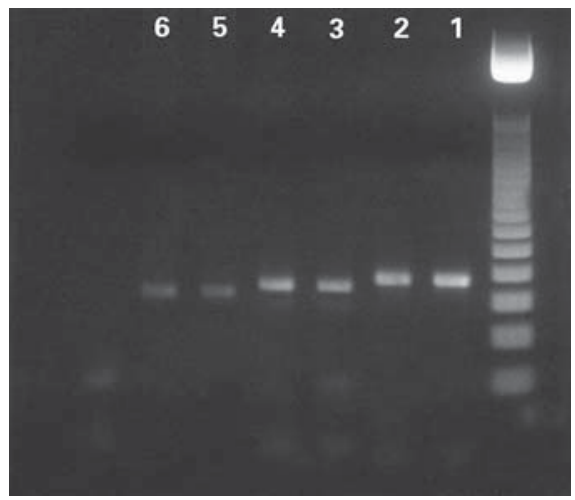

Fig. 1. PCR-based genotyping of $\mathrm{HGV}$ of the isolates. Lanes $1,2=$ RT-n-PCR-positive samples (188 bp); lanes 3, $4=$ two isolates of genotype 2 (183 bp); lanes 5, 6 = 161-bp amplicon amplified with $\mathrm{P} 1$ and $\mathrm{P} 2$ primer; $\mathrm{M}=50$-bp DNA ladder (Promega).

quence analysis. Cycle sequencing was done by the chain termination method using fluorescent dye termination (ABI PRISM ${ }^{\mathrm{TM}}$, Foster City, Calif., USA). Products were separated in an automated DNA genetic analyzer (ABI 310 Prism Perkin-Elmer Corp., Foster City, Calif., USA). The nucleotide sequences were deposited in the EMBL/GenBank databases under the accession numbers AY324428, AY324429 and AY324430. Sequences were compiled and aligned using Clustal W (v1.8). The phylogenetic tree was generated comparing the study sequences with earlier reported sequences using the neighbor-joining method in the Treecon program.

\section{Statistical Analysis}

The Fisher's exact and Mann-Whitney U tests were used for statistical evaluation. The values of $\mathrm{p}<0.05$ were accepted as statistically significant.

\section{Results}

HGV RNA was detected in $9(10.2 \%)$ of the $89 \mathrm{HD}$ patients by RT-n-PCR (fig. 1). Table 2 shows the characteristics of the $89 \mathrm{HD}$ patients, according to their $\mathrm{HGV}$ RNA status. Anti-HCV (in 6 patients, 6.7\%) and HBsAg (in 1 patient, 1.1\%) were also detected. Of the 9 patients with $\mathrm{HGV}$ RNA, 2 were also seropositive for anti-HCV and but not for HBsAg. Thus, $22.2 \%$ of the patients with $\mathrm{HGV}$ infection were also seropositive for anti-HCV while the 30 healthy individuals were negative for HGV RNA, anti-HCV and HBsAg. The mean duration of HD therapy in the HGV RNA-positive patients $(168.2 \pm 50.1$ weeks) was significantly longer than in the HGV RNAnegative patients $(79.9 \pm 15.9$ weeks, $\mathrm{p}<0.05)$. The
Table 2. Characteristics of 89 HD patients, according to their $H G V$ RNA status

\begin{tabular}{llll}
\hline Patient characteristics & \multicolumn{2}{l}{ Findings in patients with } & \multirow{2}{*}{ p value } \\
& HGV RNA & \\
\cline { 2 - 3 } & positive & negative & \\
\hline Patients & $9(10.2 \%)$ & $80(89.8 \%)$ & $<0.05$ \\
Age, years (mean \pm SD) & $49 \pm 21.08$ & $49.4 \pm 17.3$ & NS \\
Male patients & $3(33.3 \%)$ & $43(53.7 \%)$ & NS \\
Female patients & $6(66.7 \%)$ & $37(46.3 \%)$ & NS \\
Weeks on HD (mean \pm SD) & $168.2 \pm 50.1$ & $79.9 \pm 15.9$ & $<0.05$ \\
Blood transfusions & $9(100 \%)$ & $80(100 \%)$ & \\
Renal transplantations ${ }^{1}$ & - & - & \\
Patients with elevated ALT & $3(33.3 \%)$ & $2(2.5 \%)$ & \\
ALT levels, U/1 & $54 \pm 21.6$ & $15.2 \pm 1.2$ & $<0.05$ \\
Anti-HCV & & & \\
$\quad$ Positive patients & $2(22.2 \%)$ & $4(5 \%)$ & NS \\
$\quad$ Negative patients & $7(77.8 \%)$ & $76(95 \%)$ & \\
Serum HBsAg & & & \\
$\quad$ Positive patients & - & $1(1.2 \%)$ & NS \\
$\quad$ Negative patients & $9(100 \%)$ & $79(98.8 \%)$ & \\
\hline
\end{tabular}

NS $=$ Nonsignificant

${ }^{1} \mathrm{~A}$ minus sign denotes patients who did not receive renal transplantation.

${ }^{2}$ A minus sign denotes a negative test.

mean level of ALT in the HGV RNA-positive patients $(54 \pm 2.6 \mathrm{U} / \mathrm{l})$ was also significantly greater than in the HGV RNA-negative patients $(15.2 \pm 1.2 \mathrm{U} / 1, \mathrm{p}<0.05)$. There was no significant difference between the HGV RNA-positive and HGV RNA-negative patients regarding age, sex, serum anti-HCV and HBsAg.

To determine genotype distribution, the $9 \mathrm{HGV}$-positive samples were subjected to PCR with genotype-specific primers. Mix A buffer allowed for the specific detection of PCR products for types 1 and 3, and mix B for types 2 and 4, respectively. All $9 \mathrm{HGV}$-positive samples were identified as type $2 \mathrm{HGV}$ based on PCR with the genotype-specific primers (fig. 1). The specificity of the results obtained by the PCR genotyping system was confirmed by sequencing analysis. The sequence analysis of 5' UTR of the $3 \mathrm{HGV}$ isolates showed that all 3 belonged to subgroup 2a (fig. 2). Table 3 shows clinical, serological, and virological features of the $9 \mathrm{HD}$ patients who were infected with HGV. 


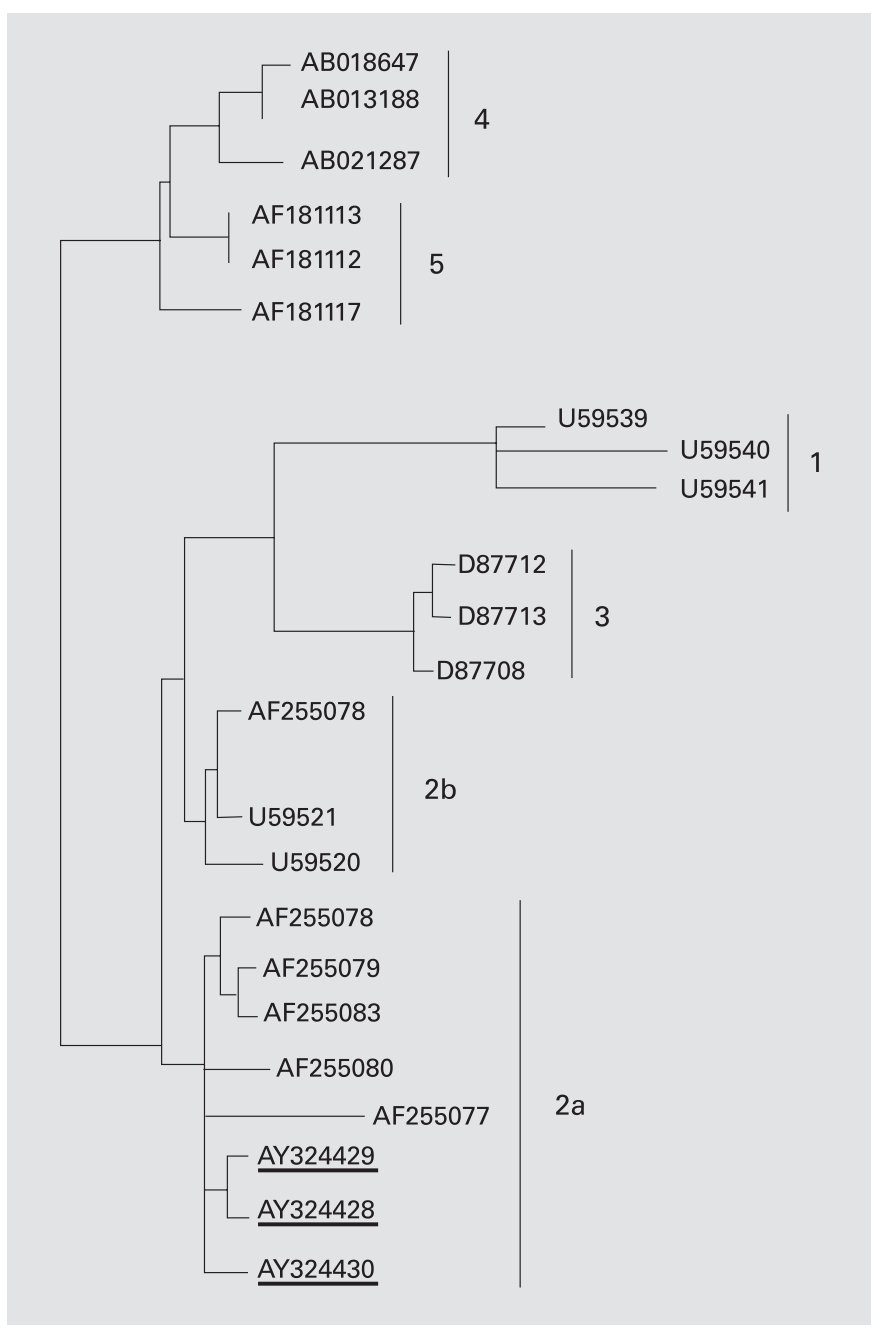

Fig. 2. Phylogenetic tree of three $\mathrm{HGV}$ isolates from East Anatolia, Turkey, generated by comparison of a 104-bp sequence in the $5^{\prime}$ UTR of HGV. This tree was created using the neighbor-joining method in the Treecon (1.3b) program.

\section{Discussion}

It is known that HD patients are at increased risk for HGV infection [14, 19-21]. To the best of our knowledge, our study is the third report evaluating the prevalence of serum HGV RNA in HD patients in Turkey. Two previous studies $[22,23]$ found the prevalence of HGV RNA in HD patients to be 34.6 and $25 \%$, respectively. In the present study, the prevalence of HGV RNA infection in patients was $10.2 \%$ compared to $3-57 \%[9,19]$ in previous studies.

HGV and HCV belong to the same family of flaviviridae. The clinical characteristics and risk factors of $\mathrm{HGV}$
Table 3. Characteristics of 9 HD patients who were infected with $\mathrm{HGV}$

\begin{tabular}{llclll}
\hline Patient & $\begin{array}{l}\text { Age } \\
\text { years/sex }\end{array}$ & $\begin{array}{l}\text { Duration of } \\
\text { HD, weeks }\end{array}$ & $\begin{array}{l}\text { ALT } \\
\text { U/l }\end{array}$ & $\begin{array}{l}\text { Anti- } \\
\text { HCV }^{1}\end{array}$ & $\begin{array}{l}\text { HGV } \\
\text { genotype }\end{array}$ \\
\hline 1 & 58/F & 3 & 44 & - & 2 \\
2 & $21 / \mathrm{F}$ & 104 & 25 & - & 2 \\
3 & $39 / \mathrm{F}$ & 468 & 33 & + & 2 \\
4 & $69 / \mathrm{M}$ & 3 & 11 & - & 2 \\
5 & $55 / \mathrm{F}$ & 208 & 12 & - & 2 \\
6 & $25 / \mathrm{M}$ & 52 & 142 & - & 2 \\
7 & $30 / \mathrm{M}$ & 360 & 188 & + & 2 \\
8 & $81 / \mathrm{F}$ & 156 & 11 & - & 2 \\
9 & $63 / \mathrm{F}$ & 260 & 20 & - & 2 \\
\hline
\end{tabular}
test.

${ }^{1}$ A plus sign denotes a positive test, and a minus sign a negative

infection may be similar to those of HCV infection. In our study, anti-HCV seropositivity was less common and was detected in only 6 patients $(6.7 \%)$, including 2 who were also infected with $\mathrm{HGV}$. Thus, HD patients are at risk for both $\mathrm{HGV}$ and $\mathrm{HCV}$ infections, and blood transfusion may be the route of transmission of the two viruses in these patients. It is possible that our study failed to show any relationship between HGV infection and inflammation of the liver because of the limited number of patients in our study and because, moreover, 1 patient who had elevated ALT level (188 U/l) was also infected with $\mathrm{HCV}$. HGV is transmitted mainly by blood transfusion. In the current study, all transmission routes of $\mathrm{HGV}$ infection had not been clearly identified because all patients received blood transfusion.

Indeed, blood transfusion is the best-known transmission route of HGV RNA infection and all of our patients have a history of blood transfusion. In our study, the prevalence of HGV RNA (10.2\%) was higher than anti-HCV seropositivity, probably because blood for transfusion had been serologically tested for anti-HCV since 1996 in Turkey. The 2 patients infected with $\mathrm{HCV}$ as well as $\mathrm{HGV}$ had been undergoing maintenance HD for a long period of time (468 and 360 weeks). We did not find any patient co-infected with $\mathrm{HBV}$ and $\mathrm{HGV}$, probably because blood for transfusion had been examined for $\mathrm{HBV}$, and $\mathrm{HD}$ patients who were negative for $\mathrm{HBsAg}$ were vaccinated against HBV.

It is known that the prevalence of HGV RNA is significantly correlated with the duration of $\operatorname{HD}[9,24]$. In 
the current study, the mean duration of HD in the HGV RNA-positive patients (168.2 \pm 50.1 weeks $)$ was significantly longer than in the HGV RNA-negative patients $(79.9 \pm 15.9$ weeks, $\mathrm{p}<0.05)$ similar to other published reports $[9,23]$. The mean level of ALT in the HGV RNApositive patients $(54.0 \pm 21.6 \mathrm{U} / \mathrm{l})$ was also significantly higher than in the HGV RNA-negative patients (15.2 \pm $1.24 \mathrm{U} / \mathrm{l}, \mathrm{p}<0.05)$ in contrast to other published reports $[20,21]$, probably because there is no association between elevated levels of ALT and HGV RNA positivity.

Genotyping studies of HGV have been mainly conducted in industrialized [17] countries, hence it is not possible to determine the worldwide distribution of $\mathrm{HGV}$. However, in Turkey, HGV genotyping done among renal transplant recipients in Izmir, West Anatolia [25], showed that the dominant genotype was type 2 as observed in this study in East Anatolia, Turkey. However, molecular characterization of a larger number of HGV isolates may reveal further genotypes in Turkey.

\section{Conclusion}

HD patients are at increased risk of $\mathrm{HGV}$ infection in East Anatolia, Turkey. Anti-HCV seropositivity was lower in HGV RNA-positive patients than expected. Moreover, there was no co-infection with HBV. All the HGV isolates belonged to genotype 2 .

\section{References}

$\checkmark 1$ Simons JN, Leary TP, Dawson GJ, Pilot-Matias TJ, Muerhoff AS, Schlauder GG, Desai SM, Mushahwar IK: Isolation of novel viruslike sequences associated with human hepatitis. Nat Med 1995; 1:564-569.

-2 Linnen J, Wages J Jr, Zhang-Keck ZY, Fry KE, Krawcyznski KZ, Alter H, et al: Molecular cloning and disease association of hepatitis $\mathrm{G}$ virus: A transfusion-transmissible agent. Science 1996;271:505-508.

-3 Lopez-Alcorocho JM, Millan A, Garcia-Trevijano ER, Bartolome J, Ruiz-Moreno M, Otero M, Carreno V: Detection of hepatitis GB virus type C RNA in serum and liver from children with chronic viral hepatitis B and C. Hepatology 1997;25:1258-1260.

-4 Kao JH, Chen W, Chen PJ, Lai MY, Chen DS: Liver and peripheral blood mononuclear cells are not major sites for GB virus-C/hepatitis G virus replication. Arch Virol 1999;144:21732183.

5 Pramoolsinsap C, Sirikulchayanonta V, Busakorn W, Poovorawan Y, Hirsch P, Theamboonlers A, Lerdverasirikul P: Coinfections with hepatitis $\mathrm{G}$ and/or $\mathrm{C}$ virus in hepatitis Belevated chronic liver disease. Southeast Asian J Trop Med Public Health 1999;30:741-749.

-6 Kleinman S: Hepatitis G virus biology, epidemiology, and clinical manifestations: Implications for blood safety. Transfus Med Rev 2001; 15:201-212.

7 Wreghitt TG: Blood-borne virus infections in dialysis units. Rev Med Virol 1999;9:101109.

-8 Theilmann L, Burkhardt HD, Galle PR, Gmelin K, Kommerell B, Pfaff E: Detection of antibodies against pre-S1 proteins in sera of patients with hepatitis B virus infection by ELISA using a pre-S fusion protein expressed in $E$. coli. Arzneimittelforschung 1988;38:18561858.

-9 Fabrizi F, Martin P: GBV-C/HGV infection in end-stage renal disease. J Nephrol 1999;12: 131-139.
10 Sheng L, Soumillion A, Beckers N, Wu CG, Verslype C, Nevens F, Pirenne J, Aerts R, Kosala H, Fevery J, Yap SH: Hepatitis G virus infection in acute fulminant hepatitis: Prevalence of $\mathrm{HGV}$ infection and sequence analysis of a specific viral strain. J Viral Hepat 1998;5: 301-306.

11 Utsunomiya S, Yoshioka K, Wakita T, Seno H, Takagi K, Ishigami M, Yano M, Watanabe K, Kobayashi M, Watanabe K, Kishimoto H, Kakumu S: TT virus infection in hemodialysis patients. Am J Gastroenterol 1999;94:35673570 .

12 Huang JJ, Lee WC, Ruaan MK, Wang MC, Chang TT, Young KC: Incidence, transmission, and clinical significance of hepatitis $\mathrm{G}$ virus infection in hemodialysis patients. Eur $\mathrm{J}$ Clin Microbiol Infect Dis 2001;20:374-379.

13 Dai CY, Yu ML, Chuang WL, Sung MH, Lin ZY, Chen SC, Hsieh MY, Wang LY, Tsai JF, Chang WY: Epidemiology and clinical significance of chronic hepatitis-related viruses infection in hemodialysis patients from Taiwan. Nephron 2002;90:148-153.

14 Hinrichsen H, Leimenstoll G, Stegen G, Schrader H, Folsch UR, Schmidt WE: PHV Study Group: Prevalence of and risk factors for hepatitis G (HGV) infection in haemodialysis patients: A multicentre study. Nephrol Dial Transplant 2002;17:271-275.

-15 Loureiro CL, Alonso R, Pacheco BA, Uzcategui MG, Villegas L, Leon G, De Saez A, Liprandi F, Lopez JL, Pujol FH: High prevalence of $\mathrm{GB}$ virus $\mathrm{C} /$ hepatitis $\mathrm{G}$ virus genotype 3 among autochthonous Venezuelan populations. J Med Virol 2002;68:357-362.

16 Tucker TJ, Smuts HE: GBV-C/HGV genotypes: Proposed nomenclature for genotypes 1-5. J Med Virol 2000;62:82-83.

17 Smith DB, Cuceanu N, Davidson F, Jarvis LM, Mokili JL, Hamid S, Ludlam CA, Simmonds P: Discrimination of hepatitis $G$ virus/ GBV-C geographical variants by analysis of the 5' non-coding region. J Gen Virol 1997:78: 1533-1542.
18 Naito H, Abe K: Genotyping system of GBV$\mathrm{C} / \mathrm{HGV}$ type 1 to type 4 by the polymerase chain reaction using type-specific primers and geographical distribution of viral genotypes. $\mathrm{J}$ Virol Methods 2001;91:3-9.

19 Masuko K, Mitsui T, Iwano K, Yamazaki C, Okuda K, Meguro T, Murayama N, Inoue T, Tsuda F, Okamoto H, Miyakawa Y, Mayumi M: Infection with hepatitis GB virus $\mathrm{C}$ in patients on maintenance hemodialysis. N Engl $\mathrm{J}$ Med 1996;334:1485-1490.

20 Martin P, Fabrizi F, Dixit V, Brezina M, Gerosa S, Russell J, Conrad A, Gitnick G: Epidemiology and natural history of hepatitis $\mathrm{G}$ virus infection in chronic hemodialysis patients. Am J Nephrol 1999; 19:535-540.

21 Fernandez JL, Valtuille R, Hidalgo A, del Pino $\mathrm{N}$, Lef L, Rendo P: Hepatitis G virus infection in hemodialysis patients and its relationship with hepatitis $\mathrm{C}$ virus infection. Am J Nephrol 2000;20:380-384

22 Gunaydin M, Bedir A, Akpolat T, Kuku I, Pekbay A, Esen S, Ozyilkan E, Arik N, Cengiz K: Prevalence of serum HGV-RNA among hemodialysis patients in Turkey. Infection 1997;25: 307-309.

$\checkmark 23$ Hizel N, Tuncbilek S, Boyacioglu S, Ozdemir $\mathrm{N}$, Haberal M: Hepatitis G virus infection in haemodialysis patients and its relationship with hepatitis $C$ virus RNA positivity. Scand $J$ Infect Dis 1998;30:451-454.

24 de Lamballerie X, Charrel RN, Dussol B: Hepatitis $\mathrm{GB}$ virus $\mathrm{C}$ in patients on hemodialysis. N Engl J Med 1996;334:1549.

25 Erensoy S, Zeytinoglu A, Goksel S, Ozacar T, Ozkahya M, Ok E, Tuumlrkoglu S, Bilgic A: $\mathrm{GB}$ virus $\mathrm{C} /$ hepatitis $\mathrm{G}$ virus infection among renal transplant recipients in Izmir, Turkey: Molecular analysis of phylogenetic groups. Int $\mathrm{J}$ Infect Dis 2002;6:242-243. 